\title{
EFEK PROMOSI ASI EKSKLUSIF PADA PERTUMBUHAN ANAK
}

\author{
Kun Aristiati Susiloretni', Yayi Suryo Prabandari2, Hamam Hadi³, Yati S Sunarto ${ }^{4}$ \\ ${ }^{1}$ Departement of Nutrition, Semarang Health Polytechnic MoH RI \\ 2Department of Public Health, Faculty of Medicine,Gadjah Mada University \\ ${ }^{3}$ Center for Health and Human Nutrition (CHHN), Faculty of Medicine, Gadjah Mada University \\ ${ }^{4}$ Department of Paediatrics, Faculty of Medicine, Gadjah Mada University \\ aristiati@yahoo.com
}

\begin{abstract}
ABSTRAK
Tujuan penelitian ini melihat pengaruh promosi ASI eksklusif secara multilevel pada pertumbuhan anak. Penelitian ini menggunakan desain experiment kuasi pre dan post test kontrol group terhadap promosi ASI eksklusif melibatkan 163 ibu hamil dan keluarganya di Demak, Jawa Tengah. Pertumbuhan berat dan tinggi badan anak diukur pada bulan ke-2, ke-4, ke-6 dan ke-28. Hasil penelitian menunjukkan bahwa skor Z BB/U sepanjang waktu dan pada umur periode 6-28 bulan serta kenaikan berat badan pada periode umur 2-6 bulan mengalami perbaikan. Perbedaan pengaruh promosi secara multilevel tidak ditemukan pada pertambahan parameter berat badan, tinggi badan, proporsi tinggi dan berat badan dan juga pada indeks berat menurut tinggi badan, dan pada gangguan pertumbuhan antara kelompok kontrol dan intervensi secara signifikant tidak ditemukan. Disarankan dilakukan penelitian sejenis namun dengan desain randomized controlled trial dengan mempertimbangkan faktor penggangu. Selain itu pemerintah daerah juga dapat menerapkan metoda dan materi yang sama seperti dalam penelitian ini.
\end{abstract}

Kata kunci: promosi secara multilevel, pencapaian pertumbuhan, skor-Z

\section{ABSTRACT}

\section{EFFECT OF PROMOTION OF EXCLUSIVE BREASTFEEDING IN CHILD GROWTH}

The effectiveness of exclusive breastfeeding promotion on increasing its duration and proportion has been revealed, but not on child growth. The objective of this article is to assess the effect of multilevel promotion of exclusive breastfeeding on child growth. A quasi experiment of the promotion with pre-posttest control group design was applied at Demak, Central Java Province. A total of 163 pregnant women and their families were participated. Children' growths were measured at 2, 4, 6, and 28 months. The results showed that weight for age $z$ score overtime, weight gained at 2 to 6 months and weight for age $z$ score of 6-28 months were improved. There was no significance different of slope overtime on (a) length and weight gain, (b) length-for-age, and weight-for-length $z$ scores, and (c) under nutrition prevalence between the intervention and the control group. The multilevel promotion of exclusive breastfeeding could improve weight for age $\mathbf{z}$ score but was not found to growth faltering. It is suggested to do the same study but using gold standard randomized controlled trial considered confounding factors. In addition, the local government could adopt the method and material used in this study.

Keywords: multilevel promotion, growth increment, z score

\section{PENDAHULUAN}

$\mathrm{M}$ enyusui eksklusif selama enam bulan pertama kehidupan direkomendasikan karena menyusui eksklusif penting dalam menurunkan besar risiko dan angka kesakitan, dan kematian bayi bila tidak menyusui eksklusif.1,2 Bayi berusia 0-3 bulan yang sudah diberi makanan tanpa air susu ibu (ASI) mempunyai risiko kematian 15,1 kali lipat karena diare, dan empat kali lipat karena infeksi saluran pernafasan akut. ${ }^{3}$ Bahkan, ASI eksklusif selama enam bulan pertama kehidupan dapat mengurangi 13 persen dari angka kematian bayi. ${ }^{1}$

Menyusui eksklusif selama enam bulan dikhawatirkan dapat mengganggu pertumbuhan. Anak yang disusui eksklusif kurang dari dua bulan mempunyai pertambahan berat badan 348 gram (95\% Cl 69 - 626 gram) lebih tinggi dibandingkan dengan yang disusui eksklusif lebih dari lima bulan. ${ }^{4}$ Pada systematic review tentang durasi optimal menyusui eksklusif tidak ditemukan bukti obyektif dari 'weanling dilemma'. Di negara-negara berkembang atau sedang berkembang bayi 
yang ASI eksklusif selama enam bulan tidak mengalami defisit pertumbuhan pada bayi. 5,6,7 Penelitian Kramer menunjukkan bahwa bayi yang disusui eksklusif selama tiga bulan sedikit lebih baik dalam pencapaian berat badan dibandingkan dengan eksklusif selama enam bulan, tetapi bayi yang disusui eksklusif selama enam bulan tinggi badan tumbuh lebih cepat pada usia sembilan bulan dan 12 bulan. ${ }^{8}$ Beberapa penelitian menunjukkan bahwa bayi yang menyusu secara eksklusif tidak menunjukkan kegagalan pertumbuhan. $9,10,11,12$

Hal ini mendorong dilakukannya upaya dukungan, promosi dan proteksi menyusui secara eksklusif yang dilakukan pemerintah maupun masyarakat melalui program-program atau penelitian pendukung. Pelaksanaan intervensinya bisa dalam bentuk intervensi tunggal atau jamak. Intervensi jamak atau kompleks biasanya lebih efektif daripada intervensi tunggal karena menangani beberapa faktor risiko atau determinan. ${ }^{13}$

Riset promosi multilevel ASI eksklusif telah membuktikan peningkatan durasi dan proporsi menyusui secara eksklusif. Durasi menyusui meningkat, yaitu 0.1 minggu pada kelompok kontrol dibandingkan dengan 18 minggu pada kelompok intervensi. Prevalensi menyusui secara eksklusif enam bulan sebesar 3,7 persen di kelompok kontrol dan 37,0 persen di kelompok intervensi. ${ }^{14}$ Artikel ini ditujukan untuk mengetahui efek promosi menyusui secara eksklusif pada pertumbuhan, yaitu (a) pertambahan tinggi dan berat badan dan tinggi badan.

\section{METODE PENELITIAN}

\section{Desain dan sampel}

Makalah ini merupakan bagian hasil penelitian dari artikel yang telah dipublikasi, sehingga metode penelitian dan intervensi secara detail telah ditulis pada artikel tersebut. ${ }^{14}$ Secara singkat dijelaskan bahwa penelitian ini merupakan eksperimen kuasi nonrandomize pretest posttest control group design with repeated measure. Penelitian dilakukan di dua wilayah puskesmas di Kabupaten Demak yaitu Puskesmas Guntur 1 sebagai daerah intervensi dan Puskesmas Gajah sebagai kontrol. Intervensi yang diberikan adalah promosi multilevel ASI eksklusif. Kegiatan yang dilakukan diantaranya adalah advokasi dan pelatihan keluarga, masyarakat, dan puskesmas. Intervensi dilaksanakan pada April hingga Juni 2009. Pengukuran dilakukan pada sebelum intervensi dan setelah intervensi 8,16 , 24 minggu, dan 28 bulan yang berakhir pada November 2011.

Partisipan adalah keluarga ibu hamil dengan kriteria kehamilan lebih dari 28 minggu, kehamilan tunggal, merencanakan untuk melahirkan bayi pada bidan di wilayah penelitian, tidak bekerja, tinggal bersama suami, memiliki kontak dengan nenek atau nenek mertua atau keluarga yang dihormati, dan tidak memiliki rencana untuk pindah ke daerah lain. Sampai pengukuran minggu ke 24 didapatkan 183 ibu dan bayi yang masuk dalam studi, $81 \mathrm{di}$ kelompok intervensi dan 81 di kelompok kontrol. Pada akhir pengukuran 28 bulan, partisipan yang melengkapi pengukuran masing-masing sebanyak 72 ibu, bayi dan keluarga.

Bahan yang digunakan dalam intervensi ini dibuat berdasarkan bahan rujukan tentang ASI dari UNICEF, WHO, dan LINGKAGE yang diterjemahkan atau dimodifikasi sesuai dengan keadaan di Indonesia di antaranya buku, booklet, dan bahan presentasi dalam bentuk power point. Lebih rinci dijelaskan dalam paragraf prosedur penelitian.

Alat yang digunakan pada pengukuran variabel adalah kuesioner, alat ukur panjang bayi, timbangan bayi, microtoise, dan timbangan berat badan. Panjang badan bayi diukur dengan alat ukur panjang bayi, tinggi badan ibu diukur dengan menggunakan microtoise dengan ketelitian $0,1 \mathrm{~cm}$, berat badan ibu diukur dengan timbangan digital 'Beurer', dan berat badan bayi diukur dengan menjumlahkan berat ibu dan bayi kemudian dikurangi dengan berat ibu.

Perbedaan karakteristik awal partisipan dianalisis menggunakan Kai kuadrat atau Fisher Exact. Pertumbuhan yang diukur adalah (a) berat dan tinggi badan, (b) pertumbuhan dengan menggunakan Z-score dari BB/U, TB/U, $\mathrm{BB} / \mathrm{TB}$, dan (c) prevalensi status gizi anak dengan <-2 Z-score. Pertambahan berat badan dihitung dengan mengurangkan berat badan pengukuran, misalnya: pertambahan BB 2 bulan dihitung dari selisih $\mathrm{kg} B B$ umur 2 bulan dengan 0 bulan (berat lahir), BB 4 bulan selisih $\mathrm{kg} \mathrm{BB} 4$ bulan dengan 2 bulan, dan seterusnya. Demikian pula penghitungan untuk tinggi badan. 
Status gizi dinilai dengan indeks Z-score BB/U, menggunakan WHO Anthro for personal $\mathrm{TB} / \mathrm{U}, \mathrm{BB} / \mathrm{TB}$ dan dihitung dengan computers. ${ }^{15}$

Tabel 1

Karakteristik Awal Level Individu pada Kelompok Intervensi dan Kontrol

\begin{tabular}{|c|c|c|c|c|c|c|c|}
\hline \multirow{2}{*}{ Variabel } & \multicolumn{2}{|c|}{ Intervensi } & \multicolumn{2}{|c|}{ Kontrol } & \multicolumn{2}{|c|}{ Total } & \multirow{2}{*}{$p$} \\
\hline & $n$ & $\%$ & $n$ & $n$ & $\%$ & $\mathrm{n}$ & \\
\hline \multicolumn{8}{|l|}{$\mathrm{Ibu}$} \\
\hline \multicolumn{8}{|l|}{ Umur } \\
\hline$>25$ tahun & 51 & 63,0 & 37 & 45,1 & 88 & 53,99 & \multirow[t]{2}{*}{0,022} \\
\hline$\leq 25$ tahun & 30 & 37,0 & 45 & 54,9 & 75 & 46,01 & \\
\hline \multicolumn{8}{|l|}{ Pendidikan } \\
\hline$\geq S D$ & 28 & 34,6 & 63 & 76,8 & 91 & 55,83 & \multirow[t]{2}{*}{0,000} \\
\hline$<\mathrm{SD}$ & 53 & 65,4 & 19 & 23,2 & 72 & 44,17 & \\
\hline \multicolumn{8}{|l|}{ Pekerjaan } \\
\hline IRT & 59 & 72.84 & 71 & 86.59 & 130 & 79.75 & \multirow[t]{3}{*}{0,002} \\
\hline Petani & 19 & 23.46 & 4 & 4.88 & 23 & 14.11 & \\
\hline Swasta & 3 & 3.70 & 7 & 8.54 & 10 & 6.13 & \\
\hline \multicolumn{8}{|l|}{ Jumlah anak } \\
\hline$>1$ & 50 & 61,7 & 35 & 42,7 & 85 & 52,15 & \multirow[t]{2}{*}{0,015} \\
\hline$\leq 1$ & 31 & 38,3 & 47 & 57,3 & 78 & 47,85 & \\
\hline \multicolumn{8}{|l|}{ Anak } \\
\hline Jenis kelamin & & & & & & & \\
\hline Laki-laki & 36 & 44,4 & 41 & 50,0 & 77 & 47,24 & \multirow[t]{2}{*}{0,477} \\
\hline Perempuan & 45 & 55,6 & 41 & 50,0 & 86 & 52,76 & \\
\hline \multicolumn{8}{|l|}{ Berat badan lahir } \\
\hline$\geq 3000$ gram & 27 & 33,3 & 31 & 37,8 & 58 & 35,58 & \multirow[t]{2}{*}{0,551} \\
\hline$<3000$ gram & 54 & 66,7 & 51 & 62,2 & 105 & 64,42 & \\
\hline \multicolumn{8}{|l|}{ Ayah } \\
\hline \multicolumn{8}{|l|}{ Umur } \\
\hline$\geq 50$ tahun & 0 & 0,00 & 1 & 1,22 & 1 & 0,61 & 0,102 \\
\hline 30 - 49 tahun & 49 & 60,49 & 37 & 45,12 & 86 & 52,76 & \\
\hline$<30$ tahun & 32 & 39,51 & 44 & 53,66 & 76 & 46,63 & \\
\hline Pendidikan & & & & & & & \\
\hline$\geq \mathrm{SD}$ & 30 & 37,04 & 62 & 75,61 & 92 & 56,44 & 0,000 \\
\hline$<\mathrm{SD}$ & 51 & 62,96 & 20 & 24,39 & 71 & 43,56 & \\
\hline Pekerjaan & & & & & & & \\
\hline Petani & 35 & 43.21 & 28 & 34.15 & 63 & 38.65 & 0.617 \\
\hline Pedagang & 9 & 11.11 & 12 & 14.63 & 21 & 12.88 & \\
\hline Swasta & 25 & 30.86 & 26 & 31.71 & 51 & 31.29 & \\
\hline Buruh pabrik & 12 & 14.81 & 16 & 19.51 & 28 & 17.18 & \\
\hline Pendapatan perkap & & & & & & & \\
\hline$\geq \operatorname{Rp} 200,000,-$ & 54 & 66,67 & 61 & 74,39 & 100 & 70,55 & 0,279 \\
\hline$<\operatorname{Rp} 200,000,-$ & 27 & 33,33 & 21 & 25,61 & 63 & 29,45 & \\
\hline Nenek & & & & & & & \\
\hline Umur & & & & & & & \\
\hline$\geq 50$ tahun & 38 & 46,91 & 33 & 40,24 & 71 & 43,56 & 0,217 \\
\hline 30 - 49 tahun & 42 & 51,85 & 44 & 53,66 & 86 & 52,76 & \\
\hline$<30$ tahun & 1 & 1,23 & 5 & 6,10 & 6 & 3,68 & \\
\hline Pendidikan & & & & & & & \\
\hline$\geq \mathrm{SD}$ & 31 & 38,27 & 50 & 60,98 & 81 & 49,69 & 0,004 \\
\hline$<\mathrm{SD}$ & 50 & 61,73 & 32 & 39,02 & 82 & 50,31 & \\
\hline Pekerjaan & & & & & & & \\
\hline IRT & 9 & 11.11 & 22 & 26.83 & 31 & 19.02 & 0,000 \\
\hline Petani & 70 & 86.42 & 45 & 54.88 & 115 & 70.55 & \\
\hline Swasta & 2 & 2.47 & 15 & 18.29 & 17 & 10.43 & \\
\hline
\end{tabular}

Perbedaan pertumbuhan pada setiap titik waktu antara kelompok intervensi dan kontrol dianalisis menggunakan student t_test atau Kai kuadrat dan regresi. Regresi linear dan regresi logistik digunakan dengan mempertimbangkan variabel jenis kelamin anak, kejadian diare, 
berat badan lahir, tinggi badan ibu, umur ibu, pendidikan ibu, jumlah anak, pendidikan ayah, pendidikan nenek, dan pendapatan per kapita. Perbedaan pertumbuhan sepanjang waktu (slope overtime) dianalisis menggunakan multilevel mixed effect linear regression (xtmixed) dan logistic regression (xtmelogit). Pada analisis pertambahan berat dan tinggi badan, sebelumnya diperiksa plotting data untuk mengetahui bentuk linier atau quadratic (dengan qfit, fpfit, dan rcspline), dan didapatkan bentuk quadratic sehingga dilakukan kontrol juga dengan variabel umur, umur ${ }^{2}$, dan umur $^{3}$. Semua analisis menggunakan STATA 11.

\section{HASIL}

\section{Karakteristik partisipan}

Pada karakteristik ibu, lebih dari separuh $(54,0 \%)$ ibu berusia lebih dari 25 tahun, berpendidikan SD atau lebih $(55,8 \%)$, mempunyai anak lebih dari satu $(52,1 \%)$, dan mempunyai anak dengan berat badan lahir kurang dari 3000 gram (64,4\%). Karakteristik ibu dari kelompok intervensi dan kontrol menunjukkan tidak berbeda bermakna $(p>0,05)$ untuk jumlah anak $(p=0,48)$ dan berat bayi lahir $(p=0,55)$. Namun, persentase ibu dengan umur $>25$ tahun, pendidikan di bawah SD, dan mempunyai anak lebih dari satu di kelompok intervensi lebih tinggi dibandingkan dengan kelompok kontrol.

Pada karakteristik keluarga, lebih dari separuh ayah berusia $>30$ tahun $(53,4 \%)$ dan berpendidikan di bawah SD $(56,4 \%)$. Pada karakteristik nenek, sebanyak 56,4 persen nenek berumur $<50$ tahun dan 50,3 persen nenek berpendidikan di bawah SD. Sebanyak 61,3 persen keluarga berpenghasilan >Rp $200.000,-$. Karakteristik keluarga dari kelompok intervensi dan kontrol tidak berbeda bermakna $(p>0,05)$ untuk umur ayah $(p=0,10)$ dan umur nenek $(p=0,22)$. Pendidikan ayah dan pendidikan nenek pada kelompok intervensi lebih rendah dibandingkan dengan kelompok kontrol $(p<0,05)$. Rincian hasil analisis disajikan pada Tabel 1. Perbedaan variabel karakteristik awal pada Tabel 1 digunakan sebagai variabel kovariat untuk analisis multivariabel.

\section{Efek promosi pada pertambahan tinggi dan berat badan}

Pertambahan tinggi badan lebih panjang terjadi pada kelompok intervensi saat usia 0-2 bulan dengan selisih $1,15 \mathrm{~cm}$ lebih panjang dibandingkan dengan kelompok kontrol dan pada usia 6-24 bulan dengan selisih 0,006 cm, tetapi selisih ini tidak bermakna secara statistik. Kemudian menjadi lebih pendek pada usia empat bulan dan enam bulan.

Pada usia 28 bulan pertambahan tinggi badan dikelompok intervensi kembali menjadi lebih tinggi dibandingkan dengan kelompok kontrol. Keadaan ini secara konsisten pada setiap pengukuran dan slope overtime tidak berbeda bermakna, konsisten dengan analisis bivariat. Secara rinci hasil analisis disajikan pada Tabel 2.

Tabel 2

Perbandingan Pertambahan Berat Badan dan Tinggi Badan Anak menurut Daerah Penelitian

\begin{tabular}{|c|c|c|c|c|c|c|c|c|c|}
\hline \multirow{2}{*}{ Waktu } & \multicolumn{3}{|c|}{ Intervensi } & \multicolumn{3}{|c|}{ Kontrol } & \multirow{2}{*}{$\begin{array}{c}\text { Selisih^ } \\
\text { (95\% Conf Interval) }\end{array}$} & \multirow{2}{*}{$\begin{array}{c}\mathrm{p}^{\wedge \wedge} \\
\text { adjusted }\end{array}$} & \multirow{2}{*}{$\begin{array}{c}\mathrm{p}^{\wedge \wedge \wedge} \\
\text { overtime }\end{array}$} \\
\hline & mean & \pm & SD & mean & \pm & SD & & & \\
\hline \multicolumn{10}{|c|}{ Pertambahan panjang badan $(\mathrm{cm} / \mathrm{bl})$} \\
\hline $0-2$ bulan & 4.75 & \pm & 1,28 & 3.60 & \pm & 1,19 & $1,146(-0,083 ; 2,375)$ & 0.458 & 0.870 \\
\hline 2-4 bulan & 1,70 & \pm & 0,98 & 1,90 & \pm & 1,01 & $-0,197(-0,507 ; 0,112)$ & 0.275 & \\
\hline 4-6 bulan & 1.29 & \pm & 0,81 & 1.37 & \pm & 0,84 & $-0,079(-0,333 ; 0,175)$ & 0.463 & \\
\hline $6-28$ bulan & 0,92 & \pm & 0,14 & 0,92 & \pm & 0,18 & $0.006(-0,048 ; 0,060)$ & 0.147 & \\
\hline \multicolumn{10}{|c|}{ Pertambahan berat badan $(\mathrm{kg} / \mathrm{bl})$} \\
\hline $0-2$ bulan & 0,98 & \pm & 0,34 & 1,03 & \pm & 0,29 & $-0,050(-0,149 ; 0,048)$ & 0.872 & 0.373 \\
\hline 2-4 bulan & 0,57 & \pm & 0,29 & 0,62 & \pm & 0,24 & $-0,040(-0,122 ; 0,041)$ & 0.520 & \\
\hline 4-6 bulan & 0,41 & \pm & 0,33 & 0,32 & \pm & 0,28 & $0,087(0,007 ; 0,169)^{*}$ & $0.049^{*}$ & \\
\hline $6-28$ bulan & 0,17 & \pm & 0,06 & 0,16 & \pm & 0,15 & $0,088(-0,010 ; 0,029)$ & 0.117 & \\
\hline
\end{tabular}


Pertambahan berat badan pada kelompok intervensi lebih rendah dibandingkan dengan kelompok kontrol pada usia 0-2 dan 2-4 bulan yaitu berturut-turut 0,008 dan $0,030 \mathrm{~kg}$, sedangkan saat usia dari 4-6 bulan dan 6-28 bulan menjadi lebih tinggi yaitu $0,074 \mathrm{~kg}$ dan $0,014 \mathrm{~kg}$. Analisis multivariable regresi linier menunjukkan bahwa pertambahan berat badan pada kelompok intervensi dari usia 4 hingga 6 bulan lebih rendah dibandingkan dengan kelompok kontrol setelah dikontrol beberapa variabel. Pertambahan berat badan anak umur 6 bulan di daerah intervensi lebih tinggi 0,074 $\mathrm{kg}$ dibandingkan dengan anak di daerah kontrol $(p=0,49)$. Pada usia tersebut anak yang menderita diare pertambahan berat badannya akan lebih rendah $0,083 \mathrm{~kg}$ dibandingkan dengan anak yang tidak menderita diare $(p<$ 0,05). Data disajikan pada Tabel 3.

Tabel 3

Efek Promosi pada Pertambahan Berat Badan $(\mathrm{kg})$

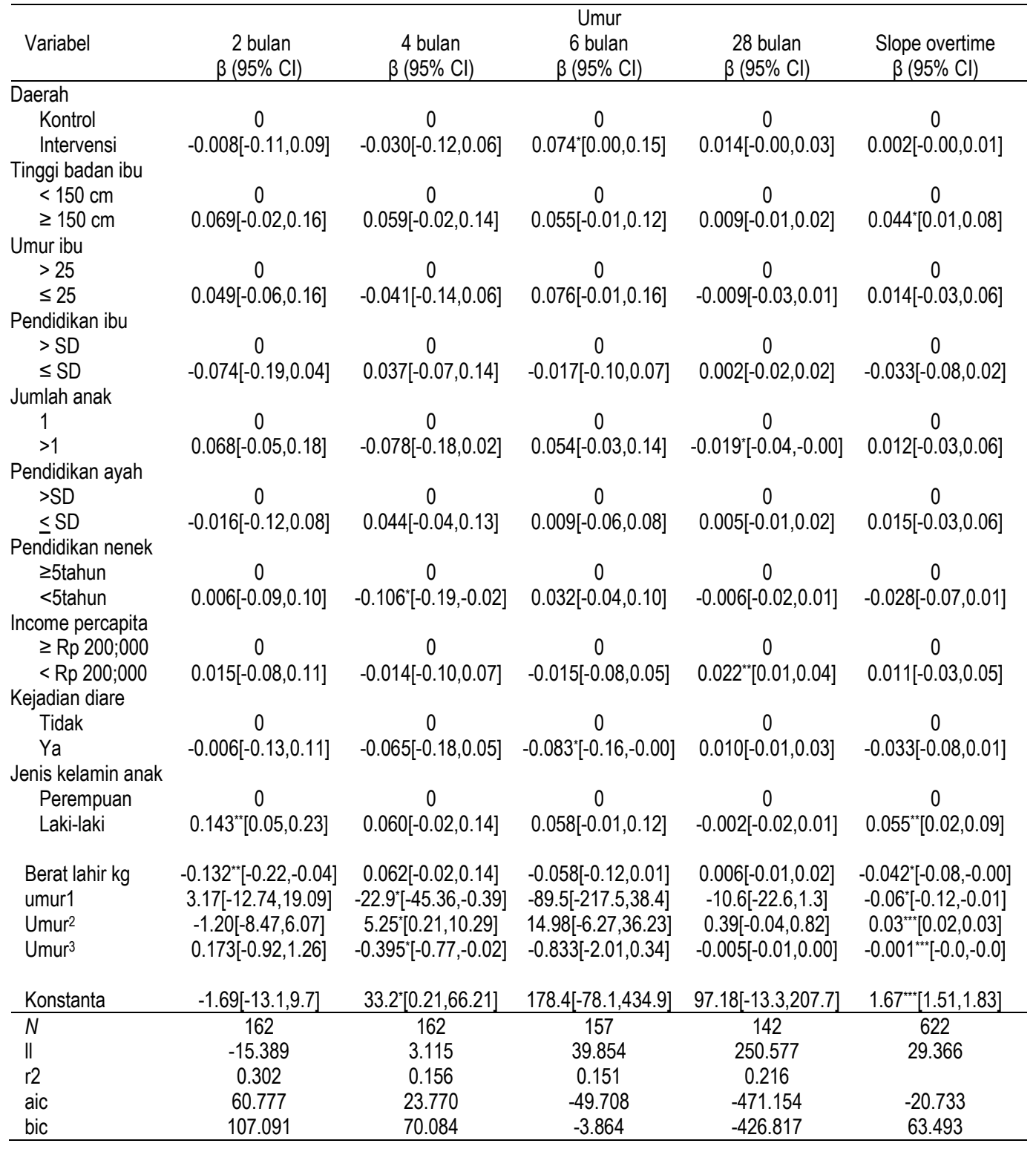

Terdapat variabel lain yang memberi kontribusi pada pertambahan berat badan bayi yaitu jenis kelamin, pendidikan nenek, dan pendapatan keluarga pada usia 28 bulan. Hasil analisis menunjukkan pada umur dua bulan anak laki-laki pertambahan berat badannya 
lebih tinggi $0,137 \mathrm{~kg}$ di bandingkan dengan anak perempuan. Pada umur 4 bulan, anak yang mempunyai nenek dengan pendidikan $<5$ tahun, pertambahan berat badannya lebih rendah $0,134 \mathrm{~kg}$ dibandingkan dengan anak yang mempunyai nenek dengan pendidikan $\geq 5$ tahun. Pada umur 28 bulan, pertambahan berat badan anak dari keluarga dengan pendapatan per kapita <Rp 200.000,- lebih tinggi 0,035 kg dibandingkan dengan anak dari keluarga dengan pendapatan perkapita $\geq R p$ 200.000,-. Apabila anak merupakan anak kedua dan seterusnya akan mempunyai berat badan lebih rendah sebesar $0,019 \mathrm{~kg}$ dibandingkan dengan anak pertama.

\section{Efektivitas promosi pada indeks pertumbuhan berdasarkan Z-score}

Pertumbuhan setiap titik waktu dianalisis menggunakan regresi linear menggunakan indeks pertumbuhan tinggi badan menurut umur (TB/U), berat badan menurut umur $(\mathrm{BB} / \mathrm{U})$, dan berat badan menurut tinggi badan (BB/TB) pada umur 2, 4, 6, dan 28 bulan. Analisis multilevel mixed effect linear regression menguji efek promosi pada slope overtime (slope of test over time) pertumbuhan dari usia 2 bulan sampai dengan 28 bulan. Nilai $p$ analisis tersebut disajikan pada Tabel 4 .

Tabel 4

Perbandingan Indeks Pertumbuhan menurut Daerah Perlakuan

\begin{tabular}{|c|c|c|c|c|c|c|c|c|c|}
\hline & \multicolumn{3}{|c|}{ Intervensi } & \multicolumn{3}{|c|}{ Kontrol } & \multirow{2}{*}{$\begin{array}{c}\text { Selisih^}^{\wedge} \\
(95 \% \text { Conf Interval) } \\
\end{array}$} & \multirow{2}{*}{$\begin{array}{c}\mathrm{p}^{\wedge \wedge} \\
\text { adjusted }\end{array}$} & \multirow{2}{*}{$\begin{array}{c}p^{\wedge \wedge \wedge} \\
\text { overtime }\end{array}$} \\
\hline & mean & \pm & SD & mean & \pm & SD & & & \\
\hline \multicolumn{10}{|c|}{ TB/U Z-score (HAZ) } \\
\hline 2 bulan & $-0,44$ & \pm & 0,95 & $-0,15$ & \pm & 1,19 & $-0,286(-0,621 ; 0,048)$ & 0.104 & \multirow[t]{4}{*}{0,435} \\
\hline 4 bulan & $-1,04$ & \pm & 1,02 & $-0,71$ & \pm & 0,98 & $-0,329(-0,639 ;-0,018)$ & 0.326 & \\
\hline 6 bulan & $-1,44$ & \pm & 1,08 & $-1,06$ & \pm & 0,87 & $-0,390(-0,695 ;-0,086)^{*}$ & 0.171 & \\
\hline 28 bulan & $-1,67$ & \pm & 0,93 & $-1,44$ & \pm & 1,31 & $-0,226(-0,606 ; 0,153)$ & 0.908 & \\
\hline \multicolumn{10}{|c|}{ BB/U Z-score (WAZ) } \\
\hline 2 bulan & $-0,50$ & \pm & 1,07 & $-0,28$ & \pm & 1,02 & $-0,216(-0,538 ; 0,107)$ & 0.399 & \multirow[t]{4}{*}{0.002} \\
\hline 4 bulan & $-0,54$ & \pm & 1,07 & 0,34 & \pm & 0,95 & $-0,194(-0,511 ; 0,118)$ & 0.849 & \\
\hline 6 bulan & $-0,06$ & \pm & 1,23 & $-0,60$ & \pm & 1,02 & $0,022(-0,327 ; 0,371)$ & 0.155 & \\
\hline 28 bulan & $-1,20$ & \pm & 1,06 & $-1,42$ & \pm & 1,07 & $0,213(-0,139 ; 0,566)$ & 0.046 & \\
\hline \multicolumn{10}{|c|}{ BB/TB Z-score (WHZ) } \\
\hline 2 bulan & $-0,12$ & \pm & 1.19 & $-0,15$ & \pm & 1.41 & $0.027(-0,376 ; 0431)$ & 0.575 & \multirow[t]{4}{*}{0,121} \\
\hline 4 bulan & 0,34 & \pm & 1,16 & 0,25 & \pm & 1,14 & $0,083(-0,272 ; 0,438)$ & 0.623 & \\
\hline 6 bulan & 0,55 & \pm & 1,20 & 0,14 & \pm & 1,21 & $0,406(0,033 ; 0,778)^{*}$ & $0.024^{*}$ & \\
\hline 28 bulan & $-0,41$ & \pm & 1,39 & $-0,91$ & \pm & 1,41 & $0,502(0,035 ; 0,969)^{*}$ & 0.104 & \\
\hline
\end{tabular}

\section{Efektivitas promosi pada Z-score indeks TB/U}

Berdasarkan indeks TB/U, rerata nilai Zscore di kelompok intervensi dan kontrol mendekati $0(-0,44$ vs $-0,15)$ pada awal umur 2 bulan. Selanjutnya menurun seiring bertambahnya usia, yaitu berturut-turut $-1,04$ vs $-0,71,-1,44$ vs $-1,06$, dan $-1,67$ vs $-1,44$ pada umur 4,6, dan 28 bulan. Secara konsisten pada semua pengukuran nilai Z-score lebih tinggi pada kelompok kontrol dibandingkan dengan kelompok intervensi. Pada pengukuran 4 bulan (selisih -0,329; 95\% Cl -0,639; -0,018), 6 bulan (selisih -0,390; 95\% Cl -0,695; -0,086), dan 28 bulan (selisih -0,226; 95\% Cl -0,606; 0,153) menunjukkan perbedaan selisih yang tidak bermakna secara statistik $(p>0,05)$.
Dengan analisis regresi linier pada setiap titik waktu, nilai Z-score TB/U pada kelompok intervensi lebih rendah dibandingkan dengan kelompok kontrol pada umur 2, 4, dan 6 bulan berturut-turut sebesar 0,30;0,147; dan 0,191. Sebaliknya, menjadi lebih tinggi sebesar 0,024 pada umur 28 bulan. Keadaan ini secara statistik tidak bermakna. Indeks TB/U pada beberapa titik waktu dipengaruhi oleh berat badan lahir, pendapatan perkapita, dan tinggi badan ibu. Pada umur 2 bulan anak yang lahir dengan berat badan $\leq 3000$ gram akan mempunyai Z-score 0,836 lebih rendah dibandingkan dengan anak yang lahir dengan berat $>3000$ gram. Pada umur 6 dan 28 bulan anak yang lahir dari ibu dengan tinggi $\geq 150 \mathrm{~cm}$ akan mempunyai Z-score berturut-turut sebesar 
0,338 dan 0,384 lebih tinggi dibandingkan dengan anak yang lahir dari ibu dengan tinggi $<150 \mathrm{~cm}$.

Efek promosi terhadap indeks pertumbuhan TB/U overtime menunjukkan bahwa anak di daerah intervensi mempunyai $Z$ score 0,005 lebih tinggi dibandingkan dengan kelompok kontrol, tetapi tidak bermakna secara statistik ( $p>0,05)$. Indeks TB/U dipengaruhi oleh tinggi badan ibu dan income percapita. Anak yang lahir dari ibu dengan tinggi $\geq 150 \mathrm{~cm}$ akan mempunyai Z-score 0,229 lebih tinggi dibandingkan dengan anak yang lahir dari ibu dengan tinggi $<150 \mathrm{~cm}$. Anak dari keluarga dengan pendapatan per kapita $<R p 200.000$,mempunyai Z-score lebih tinggi 0,195 dibandingkan dengan anak dari keluarga dengan pendapatan perkapita $\geq R p$ 200.000,-.

\section{Efek intervensi pada Z-score indeks BB/U}

Rerata Z-score dari indeks BB/U pada kelompok intervensi lebih rendah dibanding kelompok kontrol pada umur $2(-0,50$ vs $-0,28)$ dan 4 bulan $(-0,54$ vs 0,34$)$, namun berubah pada saat anak bertambah usia mulai umur 6 bulan $(-0,06$ vs $-0,60)$ dan 28 bulan $(-1,20$ vs $1,42)$. Dengan uji t keadaan tersebut secara statistik tidak bermakna (Tabel 4Error! Reference source not found.).

Analisis menggunakan regresi linear dengan dikontrol beberapa variabel, nilai Zscore indeks BB/U saat umur 2 bulan dan 4 bulan pada kelompok intervensi secara lebih rendah dibandingkan dengan kelompok kontrol berturut-turut sebesar 0,153 dan 0,023. Pada 6 bulan dan 28 bulan, Z-score kelompok intervensi menjadi lebih tinggi yaitu sebesar 0,229 dan 0,380. Kondisi tersebut diatas secara statistik tidak bermakna, kecuali pada saat anak usia 28 bulan. Pada umur 28 bulan, anak yang mendapatkan intervensi promosi ASI mempunyai Z-score sebesar 0,380 lebih tinggi dibandingkan dengan anak yang tinggal di daerah kontrol. Pada umur tersebut anak dari keluarga dengan pendapatan per kapita $<\mathrm{Rp}$ 200.000,- mempunyai Z-score lebih tinggi dibandingkan dengan anak dari keluarga dengan pendapatan >Rp 200.000,-.

Indeks BB/U pada umur tertentu juga dipengaruhi oleh berat badan lahir, tinggi badan ibu, pendidikan nenek, dan pendapatan perkapita. Pada umur 2 bulan, anak yang lahir dengan berat badan $\leq 3000$ gram akan mempunyai Z-score 0,807 lebih rendah dibandingkan dengan anak yang lahir dengan berat $>3000$ gram. Pada umur 4 bulan, anak yang lahir dari ibu dengan tinggi $\geq 150 \mathrm{~cm}$ akan mempunyai Z-score 0,260 lebih tinggi dibandingkan dengan anak yang lahir dari ibu dengan tinggi $<150 \mathrm{~cm}$ dan anak yang mempunyai nenek dengan pendidikan $\leq 5$ tahun akan mempunyai Z-score lebih rendah 0,283 dibandingkan dengan anak yang mempunyai nenek dengan pendidikan $>5$ tahun .

Efek intervensi pada slope over time dari Zscore indeks BB/U, kelompok intervensi mempunyai nilai lebih tinggi 0,017 dibandingkan dengan kelompok kontrol $(p=0,002)$. Z-score indeks $\mathrm{BB} / \mathrm{U}$ dipengaruhi juga oleh pendidikan nenek. Anak yang mempunyai nenek dengan pendidikan $\leq 5$ tahun akan mempunyai Z-score lebih rendah 0,184 dibandingkan dengan anak yang mempunyai nenek dengan pendidikan $>5$ tahun

\section{Efek intervensi pada Z-score indeks BB/TB}

Menurut indeks BB/TB, Z-score pada kelompok intervensi secara konsisten lebih tinggi dibandingkan dengan kelompok kontrol. Pada pengukuran saat anak berusia 6 bulan (selisih 0,406; 95\% Cl 0,033; 0,778) dan 28 bulan (selisih 0,502; 95\% Cl 0,035; 0,969) menunjukkan bahwa selisih perbedaan tersebut bermakna secara statistik dengan nalisis uji $t(p$ $<0,05)$.

Analisis regresi linier menunjukkan bahwa hanya pada saat anak umur 6 bulan, kelompok intervensi mempunyai nilai Z-score lebih tinggi 0,451 dibandingkan dengan kelompok kontrol dan secara statistik tidak bermakna. Pada umur 6 bulan Z-score BB/TB juga dipengaruhi oleh pendapatan per kapita. Anak dari keluarga dengan pendapatan per kapita $<R p$ 200.000,mempunyai Z-score lebih rendah 0,364 dibandingkan dengan anak dari keluarga dengan pendapatan >Rp 200.000,--

Terdapat faktor yang secara statistik bermakna memberikan efek pada indeks BB/TB, yaitu pendidikan nenek dan pendapatan perkapita. Pada umur 4 bulan, anak yang mempunyai nenek dengan pendidikan $\leq 5$ tahun akan mempunyai $z$-score lebih rendah 0,431 dibandingkan dengan anak yang mempunyai nenek dengan pendidikan $>5$ tahun. Pada umur 28 bulan, anak dari keluarga dengan pendapatan per kapita < Rp 200.000,- 
mempunyai Z-score lebih tinggi 0,550 dibandingkan dengan anak dari keluarga dengan pendapatan lebih dari Rp 200.000,-.

Efek intervensi pada slope over time dengan menggunakan analisis mixed effect linear regression menunjukkan bahwa pada indeks BB/TB pada kelompok intervensi mempunyai nilai Z-score lebih tinggi 0,013 dibandingkan dengan kelompok kontrol tetapi secara statistik tidak bermakna. Terdapat faktor yang secara statistik bermakna memberikan efek pada indeks BB/TB, yaitu pendidikan nenek. Anak yang mempunyai nenek dengan pendidikan $\leq 5$ tahun akan mempunyai Z-score lebih rendah 0,229 dibandingkan dengan anak yang mempunyai nenek dengan pendidikan lebih dari 5 tahun.

Tabel 5

Perbandingan Indeks Pertumbuhan $<-2$ Z-score menurut Daerah Intervensi

\begin{tabular}{|c|c|c|c|c|c|c|c|}
\hline \multirow{2}{*}{ Indeks pertumbuhan } & \multicolumn{2}{|c|}{$<-2$ Z-score } & \multicolumn{2}{|c|}{$\geq-2$ Z-score } & \multirow{2}{*}{$\begin{array}{l}p^{\wedge} \\
\text { chi }\end{array}$} & \multirow{2}{*}{$\begin{array}{c}\mathrm{p}^{\wedge \wedge} \\
\text { adjusted }\end{array}$} & \multirow{2}{*}{$\begin{array}{c}\mathrm{p}^{\wedge \wedge \wedge} \\
\text { overtime }\end{array}$} \\
\hline & $\mathrm{n}$ & $\%$ & $\mathrm{n}$ & $\%$ & & & \\
\hline \multicolumn{8}{|l|}{ TB/U (stunting) } \\
\hline \multicolumn{8}{|l|}{2 bulan } \\
\hline Kontrol & 5 & 6.10 & 77 & 93.90 & 0,75 & 0.600 & 0.597 \\
\hline Intervensi & 4 & 4.94 & 77 & 95.06 & & & \\
\hline \multicolumn{8}{|l|}{4 bulan } \\
\hline Kontrol & 8 & 9.76 & 74 & 90.24 & 0,07 & 0.142 & \\
\hline Intervensi & 16 & 19.75 & 65 & 80.25 & & & \\
\hline \multicolumn{8}{|l|}{6 bulan } \\
\hline Kontrol & 12 & 14.63 & 70 & 85.37 & 0,07 & 0.181 & \\
\hline Intervensi & 21 & 25.93 & 60 & 74.07 & & & \\
\hline \multicolumn{8}{|l|}{28 bulan } \\
\hline Kontrol & 23 & 31.94 & 49 & 68.06 & 0,29 & 0.955 & \\
\hline Intervensi & 28 & 40.58 & 41 & 59.42 & & & \\
\hline \multirow{2}{*}{\multicolumn{8}{|c|}{$\begin{array}{l}\text { BB/U (underweight) } \\
2 \text { bulan }\end{array}$}} \\
\hline & & & & & & & \\
\hline Kontrol & 3 & 3.66 & 79 & 96.34 & 0,66 & 0.792 & 0.067 \\
\hline Intervensi & 2 & 2.47 & 79 & 97.53 & & & \\
\hline \multicolumn{8}{|l|}{4 bulan } \\
\hline Kontrol & 1 & 1.22 & 81 & 98.78 & 0,05 & 0.211 & \\
\hline Intervensi & 6 & 7.41 & 75 & 92.59 & & & \\
\hline \multicolumn{8}{|l|}{6 bulan } \\
\hline Kontrol & 5 & 6.10 & 77 & 93.90 & 0,25 & 0.938 & \\
\hline Intervensi & 9 & 11.11 & 72 & 88.89 & & & \\
\hline \multicolumn{8}{|l|}{28 bulan } \\
\hline Kontrol & 19 & 26.39 & 63 & 73.61 & 0,43 & 0.071 & \\
\hline Intervensi & 15 & 20.83 & 66 & 79.17 & & & \\
\hline \multicolumn{8}{|l|}{ BB/ TB (wasting) } \\
\hline \multicolumn{8}{|l|}{2 bulan } \\
\hline Kontrol & 7 & 8.54 & 75 & 91.46 & 0,36 & 0.114 & 0.222 \\
\hline Intervensi & 4 & 4.94 & 77 & 95.06 & & & \\
\hline \multicolumn{8}{|l|}{4 bulan } \\
\hline Kontrol & 3 & 3.66 & 79 & 96.34 & 0,99 & 0.957 & \\
\hline Intervensi & 3 & 3.70 & 78 & 96.30 & & & \\
\hline \multicolumn{8}{|l|}{6 bulan } \\
\hline Kontrol & 4 & 4.88 & 78 & 95.12 & $0,044^{*}$ & & \\
\hline Intervensi & 0 & 0.00 & 81 & 100.00 & & & \\
\hline \multicolumn{8}{|l|}{28 bulan } \\
\hline Kontrol & 13 & 18.06 & 69 & 81.94 & $0,025^{*}$ & 0.103 & \\
\hline Intervensi & 4 & 5.80 & 77 & 94.20 & & & \\
\hline
\end{tabular}


${ }^{\wedge}$ analisis dengan chi2, ${ }^{\wedge \wedge}$ analisis dengan regresi logistik, ${ }^{\wedge \wedge}$ analisis dengan xtmelogit slope over time

Efektivitas promosi menurut prevalensi status gizi Z-score <-2

Ditinjau dari prevalensi status gizi kurang (Z-score <-2), analisis chi kuadrat menunjukkan tidak ada perbedaan secara bermakna pada indeks status gizi BB/U dan TB/U pada anakanak di kelompok intervensi dengan kontrol $(p>0,05)$. Hal ini berbeda jika ditinjau dari indeks $\mathrm{BB} / \mathrm{TB}$, prevalensi anak kurus $(\mathrm{BB} / \mathrm{TB}<-2 \mathrm{Z}$ score) lebih tinggi pada kelompok kontrol dibandingkan dengan kelompok intervensi $(p<0,05)$ pada saat anak usia 6 bulan $(0 \%$ vs. $4,9 \%$ ) dan 28 bulan (4,9\% vs. $15,8 \%)$. Hasil analisis disajikan pada Tabel 5. Setelah mempertimbangkan faktor karakteristik ibu anak, ayah, dan nenek dengan analisis regresi logistik, perbedaan diatas menjadi tidak bermakna secara statistik. Demikian pula bila dianalisis overtime menggunakan multilevel mixed effect logistic regression tidak ada, prevalensi anak dengan Z-score <-2 tidak menunjukkan perbedaan antara 2 kelompok .

Tabel 6

Efek Promosi pada Indeks Pertumbuhan <-2 Z-score Overtime dan 28 bulan (RR, 95\% Cl)

\begin{tabular}{|c|c|c|c|c|c|c|}
\hline & \multicolumn{3}{|c|}{ Overtime } & \multicolumn{3}{|c|}{ Per titik waktu } \\
\hline & TB/U & $\mathrm{BB} / \mathrm{U}$ & $\mathrm{BB} / \mathrm{TB}$ & TB/U & $\mathrm{BB} / \mathrm{U}$ & $\mathrm{BB} / \mathrm{TB}$ \\
\hline \multicolumn{7}{|l|}{ Daerah } \\
\hline Kontrol & 1 & 1 & 1 & 1 & 1 & 1 \\
\hline Intervensi overtime & $0.99[0.94,1.04]$ & $0.95[0.90,1]$ & $0.96[0.89,1.03]$ & & & \\
\hline Intervensi 4 bulan & & & & $\begin{array}{l}5.18[0.74,36.23] \\
488[0.733249]\end{array}$ & $\begin{array}{c}13.50[0.68,266.85] \\
358[035,36.99]\end{array}$ & 2.20[0.20,24.22] \\
\hline Intervensi 28 bulan & & & & $2.50[0.38,16.52]$ & $0.93[0.10,8.29]$ & $0.31[0.04,2.48]$ \\
\hline \multicolumn{7}{|l|}{ Jenis kelamin anak } \\
\hline Perempuan & 1 & 1 & 1 & 1 & 1 & 1 \\
\hline Laki-laki & $2.00[0.91,4.37]$ & $1.65[0.71,3.83]$ & $2.98[0.93,9.50]$ & $2.11[0.91,4.92]$ & $1.68[0.71,3.99]$ & $3.22[0.94,11.06]$ \\
\hline \multicolumn{7}{|l|}{ Kejadian diare } \\
\hline Tidak & 1 & 1 & 1 & 1 & 1 & 1 \\
\hline $\mathrm{Ya}$ & $0.83[0.40,1.72]$ & $1.33[0.58,3.03]$ & $0.35[0.10,1.20]$ & $0.81[0.37,1.77]$ & $1.26[0.54,2.95]$ & $0.35[0.10,1.26]$ \\
\hline \multicolumn{7}{|l|}{ Berat badan lahir } \\
\hline$>3000$ gram & $\frac{1}{1}$ & 1 & 1 & 1 & 1 & 1 \\
\hline$\leq 3000$ gram & $3.76^{* *}[1.61,8.77]$ & $1.47[0.60,3.59]$ & $1.67[0.50,5.55]$ & $4.28^{* *}[1.70,10.76]$ & $1.47[0.59,3.67]$ & $1.71[0.48,6.08]$ \\
\hline \multicolumn{7}{|l|}{ Tinggi badan ibu } \\
\hline$<150 \mathrm{~cm}$ & 1 & 1 & 1 & 1 & 1 & 1 \\
\hline$\geq 150 \mathrm{~cm}$ & $0.45^{*}[0.20,0.98]$ & $0.47[0.20,1.09]$ & $0.62[0.21,1.82]$ & $0.42^{*}[0.18,0.98]$ & $0.46[0.20,1.09]$ & $0.59[0.19,1.84]$ \\
\hline \multicolumn{7}{|l|}{ Umur ibu } \\
\hline $\begin{array}{l}>25 \\
\leq 25\end{array}$ & $2.17[0.82 .5 .76]$ & $\begin{array}{c}1 \\
120[0 \\
42\end{array}$ & $\stackrel{1}{1} 29507111]$ & $\begin{array}{c}1 \\
230[0806581\end{array}$ & $\begin{array}{c}1 \\
1200 \\
11\end{array}$ & $\begin{array}{c}1 \\
0\end{array}$ \\
\hline \multicolumn{7}{|l|}{ Pendidikan ibu } \\
\hline$>$ SD & 1 & 1 & 1 & 1 & 1 & 1 \\
\hline$\leq \mathrm{SD}$ & $2.65[0.98,7.23]$ & $2.38[0.83,6.81]$ & $1.69[0.41,6.99]$ & $2.87[0.97,8.46]$ & $2.46[0.83,7.27]$ & $1.71[0.38,7.62]$ \\
\hline 1 & 1 & 1 & 1 & 1 & 1 & 1 \\
\hline$>1$ & $2.46[0.92,6.59]$ & $0.66[0.22,1.93]$ & $0.24[0.06,1.02]$ & $2.65[0.91,7.67]$ & $0.64[0.21,1.94]$ & $0.23[0.05,1.05]$ \\
\hline \multicolumn{7}{|l|}{ Pendidikan ayah } \\
\hline$>\mathrm{SD}$ & 1 & 1 & 1 & 1 & 1 & 1 \\
\hline$\leq \mathrm{SD}$ & $1.02[0.44,2.34]$ & $1.08[0.44,2.63]$ & $0.54[0.15,1.88]$ & $1.01[0.41,2.49]$ & $1.08[0.43,2.69]$ & $0.53[0.14,1.97]$ \\
\hline \multicolumn{7}{|l|}{ Pendidikan nenek } \\
\hline $\begin{array}{l}\geq \text { 5tanun } \\
<5 \text { tahun }\end{array}$ & $0.84[0.37,1.90]$ & $\left.317^{*} 1 \frac{1}{25} 806\right]$ & $\begin{array}{c}1 \\
156[04011\end{array}$ & $\begin{array}{c}1 \\
0830342021\end{array}$ & $\begin{array}{c}1 \\
325 * 01\end{array}$ & $\begin{array}{c}1 \\
16250511\end{array}$ \\
\hline \multicolumn{7}{|l|}{ Income percapita } \\
\hline$\geq \operatorname{Rp} 200 ; 000$ & 1 & 1 & 1 & 1 & 1 & 1 \\
\hline$<$ Rp 200;000 & $0.76[0.34,1.71]$ & $0.38^{*}[0.16,0.95]$ & $1.09[0.36,3.27]$ & $0.75[0.32,1.79]$ & $0.37^{\star}[0.15,0.94]$ & $1.12[0.35,3.57]$ \\
\hline $\mathrm{N}$ & 630.00 & 633.00 & 630.00 & 630.00 & 633.00 & 630.00 \\
\hline ॥ & -242.91 & -159.68 & -118.84 & -232.93 & -156.12 & -113.52 \\
\hline chi2 & 53.43 & 42.39 & 22.71 & 55.88 & 42.31 & 21.68 \\
\hline aic & 515.83 & 349.36 & 267.68 & 503.85 & 350.24 & 265.04 \\
\hline bic & 582.52 & 416.12 & 334.36 & 588.32 & 434.80 & 349.51 \\
\hline
\end{tabular}

Exponentiated coefficients; 95\% confidence intervals in brackets , ${ }^{*} p<0.05,{ }^{, *} p<0.01,{ }^{* * *} p<0.001$

Dalam analisis ini didapatkan faktor yang berpengaruh pada kejadian anak pendek (stunting), anak kurus (wasting), dan anak kurang berat (underweight). Anak stunting dipengaruhi oleh faktor berat badan lahir dan tinggi badan ibu. Anak yang dilahirkan dengan 
berat $<3000$ gram akan berisiko sebesar 3,76 kali lipat untuk menjadi stunting dibandingkan dengan anak yang dilahirkan dengan berat $\geq$ 3000 gram. Anak yang dilahirkan dari ibu dengan tinggi badan $\geq 150 \mathrm{~cm}$ mempunyai risiko 55 persen lebih rendah untuk menjadi stunting dibandingkan dengan anak yang dilahirkan dari ibu dengan tinggi badan $<150 \mathrm{~cm}$.

Anak underweight dikaitkan dengan pendidikan nenek dan pendapatan per kapita. Anak yang mempunyai nenek dengan pendidikan $<5$ tahun mempunyai risiko 3,17 kali lipat untuk menjadi underweight dibandingkan dengan anak yang mempunyai nenek dengan pendidikan $\geq 5$ tahun. Anak dari keluarga dengan pendapatan per kapita $<R p 200.000$,mempunyai risiko $62 \%$ lebih rendah untuk menjadi underweight dibandingkan dengan anak dari keluarga dengan pendapatan $>\mathrm{Rp}$ 200.000,- (Tabel 6).

\section{BAHASAN}

\section{Perbandingan pertambahan berat dan panjang anak}

Hasil penelitian ini menunjukkan bahwa tidak terdapat perbedaan bermakna pada pertambahan panjang badan bayi pada umur 0 hingga 28 bulan antara kelompok intervensi dan control. Demikian pula tidak terdapat perbedaan pada berat badan bayi pada umur 0-4 bulan serta setelah 6-28 bulan. Setelah mempertimbangkan berat lahir, umur ibu, pendidikan ibu, jumlah anak, pendidikan ayah, dan pendidikan nenek, efek protektif terlihat pada pertambahan berat badan bayi pada saat umur 4-6 bulan dengan selisih pertambahan berat badan sebesar $0,100 \mathrm{~kg}(95 \% \mathrm{Cl}: 0,01$ $0,19)$ lebih tinggi pada kelompok intervensi.

Penelitian grup randomisasi PROBIT yang melibatkan 17.046 ibu dan bayi untuk diberikan perlakuan promosi ASI menggunakan cara WHO Rumah Sakit Sayang Bayi memberikan hasil yang berbeda. Bayi pada usia 1 bulan di kelompok perlakuan mempunyai rata-rata berat badan lebih tinggi dibandingkan dengan kelompok kontrol (4.341 vs. 4.280 gram). Perbedaan meningkat saat bayi usia 3 bulan (6.153 g vs. $6.047 \mathrm{gram}$ ), kemudian menurun perlahan, dan menjadi tidak ada perbedaan pada saat bayi berusia 12 bulan (10.564 g vs. 10.571 gram). ${ }^{16}$
Efek protektif menyusui eksklusif juga terdapat pada penelitian di Bangladesh yang menunjukkan bahwa menyusui eksklusif dan pendidikan gizi dapat meningkatkan berat dan panjang badan anak berat badan lahir rendah di daerah intervensi $(3620 \pm 229 \mathrm{~g}$ vs. $3315 \pm 301 \mathrm{~g}$, $p<0,001$ and $50,2 \pm 1.3 \mathrm{~cm}$ vs. $48,7 \pm 1,6 \mathrm{~cm}$; $p<0,001 .{ }^{17} \quad$ Pada penelitian PROBIT, peningkatan berat dan panjang badan anak yang menyusui eksklusif 3 bulan lebih tinggi dibandingkan dengan anak yang menyusu eksklusif 6 bulan. Efek protektif menyusui eksklusif 6 bulan pada pertumbuhan terjadi pada usia setelah 9-12 bulan, pertambahan panjang badan anak lebih cepat dibandingkan dengan anak yang menyusui eksklusif 3 bulan. ${ }^{8}$

Sebaliknya, penelitian randomisasi di San Pedro Sula Honduras menunjukkan bahwa pada populasi ekonomi rendah, ketika menyusui eksklusif diterapkan pada kelompok 4 dan 6 bulan dan diteruskan menyusui sampai saat usia 12 bulan, pertambahan berat badan anak tidak berbeda bermakna antar kelompok. Ratarata berat lahir anak Honduras lebih rendah dibandingkan bayi dari kelompok ekonomi tinggi di USA ( $2.889 \pm 482$ vs. $3.611 \pm 509$ gram), tetapi anak Honduras menunjukkan pertumbuhan lebih cepat pada bulan pertama dan akirnya berat badan menjadi sama pada usia 3 bulan. Berat dan panjang badan pada usia 4-9 bulan sama dengan anak USA tetapi lebih rendah pada saat anak usia 9-12 bulan. Hal ini disebabkan oleh perbedaan tinggi badan ibu 12 $\mathrm{cm}$ lebih rendah pada ibu Honduras. ${ }^{18}$

\section{Indeks pertumbuhan menurut pada intervensi dan kontrol}

Pada penelitian ini tidak didapatkan perbedaan secara signifikan pertumbuhan anak berdasarkan indeks pertumbuhan $T B / U$ dan $B B / T B$. Pada pengukuran dengan indeks $B B / U$, slope over time pertumbuhan dengan z-score yang lebih tinggi $0,016(95 \% \mathrm{Cl}: 0,01-0,03)$ pada anak di kelompok intervensi didandingkan dengan kelompok kontrol dan lebih tinggi 0,455 (95\% Cl: $0,15-0,76)$ saat anak usia 28 bulan pada kelompok intervensi dibandingkan dengan kelompok control.

Efektivitas promosi ASI ditunjukkan penelitian PROBIT, pengukuran BB/U Z-score berada diatas kelompok referen $(z$-score $=0)$ dan meningkat hingga umur 12 bulan terjadi pada kelompok intervensi maupun kontrol, 
mengindikasikan tidak terjadi kekurangan gizi. Rata-rata Z-score BB/U bayi yang menyusui eksklusif 1 bulan menurun tajam pada usia 1 bulan tetapi meningkat cepat sampai usia 12 bulan hingga mengikuti bayi yang menyusu eksklusif 6 bulan. Rata-rata Z-score TB/U mempunyai pola yang sama. Hanya saja kelompok yang menyusui eksklusif lebih dari 6 bulan mengalami perlambatan pertumbuhan hingga berada dibawah kelompok referen. ${ }^{16}$

Penelitian promosi menyusui eksklusif dengan disain grup randomisasi di Haryana, India yang melibatkan 1.115 bayi baru lahir menunjukkan bahwa rata-rata berat dan panjang badan pada saat anak usia 3 dan 6 bulan tidak berbeda antara kelompok perlakuan dan kontrol. Hal ini medukung pendapat bahwa tidak terjadi 'growth faltering' bila bayi menyusui eksklusif hingga 6 bulan. ${ }^{12}$ Penelitian longitudinal di Glasgow menemukan anak yang menyusu eksklusif 6 bulan mempunyai pertumbuhan normal dibandingkan dengan standar WHO. Pada pengukuran pertama saat bayi umur 15 minggu berat badan anak berkisar $6.72( \pm 0.78) \mathrm{kg}$ untuk anak laki-laki dan 6.30 $( \pm 0.64) \mathrm{kg}$ untuk anak perempuan. Pada pengukuran kedua saat bayi berusia $24( \pm 1.7)$ minggu berat badan bayi sekitar $7.84( \pm 0.91) \mathrm{kg}$ untuk anak laki-laki dan $7.37( \pm 0.75) \mathrm{kg}$ untuk anak perempuan. Ketika ibu didukung untuk mengikuti rekomendasi WHO, konsumsi ASI tinggi dan meningkat secara signifikan dari waktu ke waktu, dapat memenuhi kebutuhan energi bayi untuk pertumbuhan normal. Tidak ada bukti bahwa produksi ASI tidak cukup selama 6 bulan ASI eksklusif. ${ }^{19}$

Dalam analisis ini diungkap peran faktor tinggi badan ibu dan berat badan lahir. Tinggi badan ibu secara konsisten berpengaruh terhadap indeks $\mathrm{BB} / \mathrm{U}$ dan $\mathrm{TB} / \mathrm{U}$ pada slope over time dan nilai $z$ saat usia 28 bulan. Anak yang lahir dari ibu dengan tinggi $\geq 150 \mathrm{~cm}$ akan mempunyai Z-score 0,288 lebih tinggi dibandingkan dengan anak yang lahir dari ibu dengan tinggi $<150 \mathrm{~cm}$. Faktor tinggi badan ibu sebagai prediktor pertumbuhan anak diungkapkan oleh beberapa penelitian. Tinggi badan ibu dikaitkan dengan penurunan risiko underweight, stunting, wasting, anemia, dan kematian anak. Bahkan, anak-anak yang lahir dari ibu yang kurang dari $145 \mathrm{~cm}$ mempunyai risiko 1,71 kali lebih mungkin untuk meninggal
(95\% Cl: 1,37-2,13) dibandingkan dengan ibu dengan tinggi badan $160 \mathrm{~cm} .{ }^{20,21,22,23}$

Berat badan lahir juga konsisten berpengaruh pada pertumbuhan dengan index $\mathrm{BB} / \mathrm{U}$ dan $\mathrm{TB} / \mathrm{U}$. Anak yang lahir dengan berat badan $\leq 3000$ gram akan mempunyai Z-score 0,569 sampai 0,580 lebih rendah dibandingkan dengan anak yang lahir dengan berat $>3000$ gram. Hasil ini sesuai dengan penelitian yang melaporkan bahwa kemungkinan stunting secara signifikan meningkat karena diare, infeksi pernapasan demam, pemberian makanan tambahan dini dan berat badan lahir rendah. Pengaruh berat lahir paling kuat terjadi pada tahun pertama kehidupan anak. Menyusui, perawatan kesehatan preventif dan perawakan ibu lebih tinggi secara signifikan menurunkan kemungkinan stunting 23,24

\section{Prevalensi status gizi Z-score $<-2$ pada daerah intervensi dan kontrol}

Proporsi status gizi dilihat berdasarkan indeks $\mathrm{TB} / \mathrm{U}, \mathrm{BB} / \mathrm{U}$, dan $\mathrm{BB} / \mathrm{TB}$ dengan Z-score $<-2$ (stunting, underweight, dan wasting) tidak menunjukkan perbedaan yang bermakna. Prevalensi balita pendek cukup tinggi dengan makin bertambahnya usia, tertinggi pada saat pengukuran 28 bulan. Penelitian di Haryana India juga menemukan bahwa proporsi BB/U dan TB/U Z-score $<2$ tidak berbeda antara kelompok perlakuan dan kontrol pada semua anak maupun pada anak yang berat badan lahir rendah. Pada semua anak terdapat 3 persen anak dengan $\mathrm{TB} / \mathrm{U}<-2$ di kelompok intervensi maupun kontrol $(p=0,695)$. Pada anak dengan berat badan lahir rendah, terdapat anak dengan TB/U<- 2 sebanyak 42 persen dikelompok intervensi dan 34 persen di kelompok kontrol $(p=0,100)$ sedangkan anak dengan $B B / U<-2$ sebanyak 3 persen dan 5 persen dikelompok intervensi dan kontrol $(p=0,195)$. Hal ini mendukung pendapat bahwa tidak terjadi growth faltering bila bayi menyusui eksklusif hingga 6 bulan. ${ }^{12}$

Penelitian Kramer membandingkan anak yang menyusui eksklusif 3 bulan dan 6 bulan juga mendukung, bahwa tidak terjadi gagal tumbuh pada anak yang menyusu eksklusif 6 bulan. Bahkan terjadi catch up growth pada pertumbuhan tinggi badan saat anak usia antara 9 dan 12 bulan. Pertambahan berat badan sedikit lebih tinggi pada kelompok menyusui eksklusif 3 bulan pada semua 
pengukuran 6,9 , dan 12 bulan. Nilai Z-score <2 jarang terjadi mengingat penelitian dilakukan di negara relatif maju. Pada BB/U $<-2$ terdapat berturut-turut 0,1 , dan 1 dari 620 anak pada kelompok eksklusif 3 bulan dibandingkan dengan 2, 3, dan 4 dari 2841 pada kelompok eksklusif 6 bulan. Pada TB/U nilai $z<-2$ lebih banyak terjadi, tetapi mereka tidak berbeda secara signifikan antara 6-bulan dan kelompok 3-bulan pada 6, 9, dan 12 bulan, masingmasing: 14 dari 619 dibandingkan dengan 42 dari 2841 [RR: 1,53 (95\% Cl: 0,84, 2,78)], 14 dari 611 dibandingkan dengan 44 dari 2795 (RR: 1,46 95\% Cl: 0,80, 2,64), dan 4 dari 617 dibandingkan dengan 28 dari 2849 (RR: 0,66 $95 \% \mathrm{Cl}: 0,23,1,87)$. Seperti pada BB/U, nilai z $<-2$ pada BB/TB jarang sekali terjadi dan tidak berbeda secara statistik. ${ }^{8}$

Penelitian kohor di negara maju Iceland dan Denmark yang membandingkan anak yang menyusu eksklusif 2 bulan dan 6 bulan, menunjukkan hal yang berbeda berkaitan dengan efek overweight. Berat badan dari 6 sampai 12 bulan ditemukan lebih besar di antara bayi ASI eksklusif untuk $\leq 2$ bulan dibandingkan dengan $\geq 5$ bulan $(p=0,008)$.

Hal ini dikaitkan dengan tingginya z-skor IMT pada masa anak-anak saat umur 6 dan 10 tahun setelah dikontrol dengan berat badan lahir, negara dan durasi menyusui eksklusif $(p<0,001)$. Namun, asosiasi itu lebih kuat dalam kelompok Islandia dari yang Denmark. Meskipun durasi menyusui eksklusif tidak dikaitkan dengan IMT masa kanak-kanak saat usia 6 atau 10 tahun, penelitian ini mungkin memberikan gambaran tingkat pertumbuhan pada masa bayi, yang berkaitan dengan IMT pada masa anak-anak.

Faktor lain yang berpengaruh pada pertumbuhan bayi juga perlu dipertimbangkan ketika menilai hubungan pertumbuhan dan MPASI dini dengan kelebihan berat badan anak, seperti indeks massa tubuh ibu sebelum hamil, durasi menyusui, dan waktu pengenalan makanan pendamping. ${ }^{4,25}$

Hasil penelitian tentang efek promosi pada pertumbuhan masih memerlukan studi lanjut. Mengingat pertumbuhan anak dipengaruhi banyak faktor, sehingga perlu dilakukan penelitian yang melibatkan berbagai faktor seperti konsumsi, penyakit infeksi, menyusui, pola asuh, dan lingkungan. 7,10,26,27

\section{SIMPULAN DAN SARAN}

\section{Simpulan}

1. Tidak terdapat perbedaan bermakna pada pertambahan berat badan dan tinggi badan anak sepanjang waktu (slope overtime). Pada usia 6 bulan terjadi pertambahan berat badan lebih tinggi $0.074 \mathrm{~kg}$ lebih tinggi pada kelompok intervensi dibandingkan dengan kelompok kontrol. Ditemukan bahwa pada titik waktu tertentu terdapat pengaruh kejadian diare, tinggi badan ibu, jumlah anak, pendidikan nenek, dan pendapatan terhadap pertambahan berat badan.

2. Kelompok intervensi mempunyai Z-score BB/U sepanjang waktu (slope overtime) sedikit lebih tinggi $0,017(95 \% \mathrm{Cl} 0,01-$ 0,03 ) dibandingkan dengan anak kelompok kontrol, tetapi tidak pada Z-score TB/U dan BB/TB. Pada usia 24 bulan anak pada kelompok intervensi mempunyai Z-score BB/U lebih tinggi 0, $380(95 \% \mathrm{Cl} 0,01-$ 0,75 ) dibandingkan dengan kelompok kontrol. Ditemukan bahwa pada titik waktu tertentu terdapat pengaruh kejadian diare, tinggi badan ibu, jumlah anak, pendidikan nenek, dan pendapatan terhadap pertambahan berat badan.

3. Tidak terdapat perbedaan bermakna pada prevalensi undernutrition (Z-score $\leq 2)$ sepanjang waktu (slope overtime). Ditemukan faktor yang berpengaruh pada anak stunting yaitu berat badan lahir dan tinggi badan ibu.

\section{Saran}

1. Dari aspek ilmiah, perlu dilakukan penelitian promosi dengan desain yang lebih tepat dengan group randomized control trial untuk mendapatkan kelemahan penelitian yang minimal. Penelitian pertumbuhan perlu mempertimbangan faktor berpengaruh seperti konsumsi, penyakit infeksi, menyusui, pola asuh, dan lingkungan. Perlu juga dilakukan analisis pertumbuhan berdasarkan eksklusifitas pemberian ASI.

2. Mengingat pentingnya promosi ASI eksklusif, Peraturan Pemerintah No.33 
Tahun 2012 Tentang Pemberian Air Susu Ibu Eksklusif perlu segera dijalankan. Termasuk pendanaan, peran kementerian lain dalam promosi $\mathrm{ASI}$, dan penerapan sangsi pelanggaran WHO Code.

3. Promosi ASI eksklusif dapat dilaksanakan secara swadaya pemerintah daerah dengan menggunakan metode dan materi

\section{RUJUKAN}

1. Jones, G., Steketee, R. W., Black, R. E., Bhutta, Z. A. \& Morris, S. S.. How Many Child Deaths Can We Prevent This Year? Lancet. 2003; 362: 65-71.

2. Kramer, M. S., Chalmers, B., Hodnett, E. D., Sevkovskaya, Z., Dzikovich, I., Shapiro, S., et.al. Promotion of Breastfeeding Intervention Trial (Probit): A Randomized Trial in the Republic of Belarus. JAMA. 2001; 285: 413-20.

3. Betrán, A. P., de Onís, M., Lauer, J. A. \& Villar, J. Ecological Study of Effect of Breast Feeding on Infant Mortality in Latin America. BMJ. 2001; 323: 303.

4. Gunnarsdottir, I., Schack-Nielsen, L., Michaelsen, K. F., Sørensen, T. I. A. \& Thorsdottir, I. Infant Weight Gain, Duration of Exclusive Breast-Feeding and Childhood Bmi - Two Similar Follow-up Cohorts. Public health nutrition.2010; 13: 201-7.

5. Kramer, M. S. \& Kakuma, R. The Optimal Duration of Exclusive Breastfeeding. A Systematic Review. Geneva: World Health Organization, 2002

6. Kramer, M. \& Kakuma, R. The Optimal Duration of Exclusive Breastfeeding: A Systematic Review. Geneva: World Health Organization, 2002

7. Fewtrell, M. S., Morgan, J. B., Duggan, C., Gunnlaugsson, G., Hibberd, P. L., Lucas, A. et.al Optimal Duration of Exclusive Breastfeeding: What Is the Evidence to Support Current Recommendations? Am J Clin Nutr. 2007; 85:635S-638S.

8. Kramer, M. S., Guo, T., Platt, R. W., Sevkovskaya, Z., Dzikovich, I., Collet, J. P., et.al. Infant Growth and Health Outcomes Associated with 3 Compared with 6 Mo of Exclusive Breastfeeding. Am J Clin Nutr.2003;7: 291-5.
9. Cohen, R., Brown, K., Dewey, K., Canahuati, J. \& Landa Rivera, L. Effects of Age of Introduction of Complementary Foods on Infant Breast Milk Intake, Total Energy Intake, and Growth: A Randomised Intervention Study in Honduras. The Lancet. 1994; 344: 288-293.

10. Simondon, K. \& Simondon, F. Age at Introduction of Complementary Food and Physical Growth from 2 to 9 Months in Rural Senegal. European Journal of Clinical Nutrition. 1997; 51: 703-707.

11. Kramer, M. S., Matush, L., Vanilovich, I., Platt, R. W., Bogdanovich, N., Sevkovskaya, Z, et.al. Effects of Prolonged and Exclusive Breastfeeding on Child Height, Weight, Adiposity, and Blood Pressure at Age 6.5 Y: Evidence from a Large Randomized Trial. Am J Clin Nutr. 2007; 86: 1717-21.

12. Bhandari, N., Bahl, R., Mazumdar, S., Martines, J., Black, R. E. \& Bhan, M. K. Effect of Community-Based Promotion of Exclusive Breastfeeding on Diarrhoeal Illness and Growth: A Cluster Randomised Controlled Trial. Lancet. 2003; 361: 1418.

13. Imdad, A., Yakoob, M. Y. \& Bhutta, Z. A. Effect of Breastfeeding Promotion Interventions on Breastfeeding Rates, with Special Focus on Developing Countries. BMC Public Health. 2011;11: S24-S34.

14. Susiloretni, K. A., Krisnamurni, S., Sunarto, Widiyanto, S. Y. D., Yazid, A. \& Wilopo, S. A. The Effectiveness of Multilevel Promotion of Exclusive Breastfeeding in Rural Indonesia. American Journal of Health Promotion.2013;28(2): 44-55

15. World Health Organization. Anthro for Personal Computers, Version 2, 2007: Software for Assessing Growth and Development of the World's Children. Geneva: WHO, 2007

16. Kramer, M. S., Guo, T., Platt, R. W., Shapiro, S., Collet, J. P., Chalmers, et.al. Breastfeeding and Infant Growth: Biology or Bias? Pediatrics. 2002; 110: 343-7.

17. Thakur, S. K., Roy, S. K., Paul, K., Khanam, M., Khatun, W. \& Sarker, D. Effect of Nutrition Education on Exclusive Breastfeeding for Nutritional Outcome of Low Birth Weight Babies. European Journal of Clinical Nutrition. 2012; 66: 376-81. 
18. Cohen, R. J., Brown, K. H., Canahuati, J., Rivera, L. L. \& Dewey, K. G. Determinants of Growth from Birth to 12 Months among Breast-Fed Honduran Infants in Relation to Age of Introduction of Complementary Foods. Pediatrics. 1995; 96: 504-510.

19. Nielsen, S. B., Reilly, J. J., Fewtrell, M. S., Eaton, S., Grinham, J. \& Wells, J. C. K. Adequacy of Milk Intake During Exclusive Breastfeeding: A Longitudinal Study. Pediatrics. 2011; 128: e907-e914.

20. Özaltin, E., Hill, K. \& Subramanian, S. V. Association of Maternal Stature with Offspring Mortality, Underweight, and Stunting in Low- to Middle-Income Countries. JAMA. 2010; 303: 1507-1516.

21. Subramanian, S., Ackerson, L. K., Smith, G. D. \& John, N. A. Association of Maternal Height with Child Mortality, Anthropometric Failure, and Anemia in India. JAMA: The Journal of the American Medical Association. 2009; 301: 1691-1701.

22. Ashworth, A., Morris, S. S. \& Lira, P. I. C. Postnatal Growth Patterns of Full-Term Low Birth Weight Infants in Northeast Brazil Are Related to Socioeconomic Status. The Journal of Nutrition. 1997; 127: 1950-1956.
23. Adair, L. S. \& Guilkey, D. K. Age-Specific Determinants of Stunting in Filipino Children. The Journal of Nutrition,1997; 127: 314-320.

24. Sørensen, H. T., Sabroe, S., Rothman, K. J., Gillman, M., Steffensen, F. H., Fischer, $P$, et.al. Birth Weight and Length as Predictors for Adult Height. American Journal of Epidemiology. 1999; 149: 726729.

25. Baker, J. L., Michaelsen, K. F., Rasmussen, K. M. \& Sorensen, T. I. Maternal Prepregnant Body Mass Index, Duration of Breastfeeding, and Timing of Complementary Food Introduction Are Associated with Infant Weight Gain. Am J Clin Nutr. 2004; 80: 1579-88.

26. Onyango, A. W., Esrey, S. A. \& Kramer, M. S. Continued Breastfeeding and Child Growth in the Second Year of Life: A Prospective Cohort Study in Western Kenya. The Lancet. 1999; 354: 2041-2045.

27. Bhutta, Z. A., Ahmed, T., Black, R. E., Cousens, S., Dewey, K., Giugliani, E., et.al. What Works? Interventions for Maternal and Child Undernutrition and Survival. The Lancet. 2008; 371: 417-440. 